\title{
Modeling and Simulation of Grid Connected Hybrid Energy System and its Fault Analysis
}

\author{
Sujit Kumar Bhuyan', Prakash Kumar Hota ${ }^{2}$, Bhagabat Panda ${ }^{3}$ \\ ${ }^{1,3}$ School of Electrical Sciences, KIIT University, India \\ ${ }^{2}$ Department of Electrical Engineering, Veer Surendra Sai University of Technology, India
}

\begin{tabular}{|c|c|}
\hline Article Info & ABSTRACT \\
\hline Article history: & This paper represents a hybrid energy system (HES) consisting of \\
\hline Received Des 08, 2017 & $\begin{array}{l}\text { photovoltaic (PV), Solid Oxide Fuel Cell (SOFC), electrolyzer system and a } \\
\text { storage tank. In this proposed system a fuel cell controller is used where a }\end{array}$ \\
\hline Revised Jan 09, 2018 & PID controller is utilized to control the flow of hydrogen $\left(\mathrm{H}_{2}\right)$ through the \\
\hline Accepted Apr 10, 2018 & $\begin{array}{l}\text { valve to the SOFC to fulfill the load requirement. In this model a supervisory } \\
\text { controller is used to regulate the whole system according to load }\end{array}$ \\
\hline Keyword: & $\begin{array}{l}\text { requirement. So, when PV power is more than load requirement, then PV } \\
\text { power fulfill the required load demand as well as the extra power of PV is }\end{array}$ \\
\hline Electrolyzer & utilized to generate the hydrogen $\left(\mathrm{H}_{2}\right)$ by the help of electrolyzer, further this \\
\hline Grid & hydrogen is used as a fuel of SOFC. Also, in this proposed model different \\
\hline PV model & types of faults are considered and verified their effect on the load as well as \\
\hline Solid oxide fuel cell (SOFC) & in distribution network. The computer simulations are done for the purpose \\
\hline Storage tank & $\begin{array}{l}\text { technology and veritied its effectiveness. Hence the appropriate results } \\
\text { are obtained. }\end{array}$ \\
\hline
\end{tabular}

Copyright $@ 2018$ Institute of Advanced Engineering and Science. All rights reserved.

\section{Corresponding Author:}

Sujit Kumar Bhuyan,

School of Electrical Engg Engineering,

KIIT University,

Bhubaneswar, India.

Email: sujeet.kumar84@gmail.com

\section{INTRODUCTION}

Renewable energy sources (RESs) provides clean energy sources which is pollution free, also RESs are environmentally friendly. These renewable energy sources are cost free and continuous according to [1], [2]. H. Yang, et al. [3] describes about various RESs consists of wind energy sources (WESs), photovoltaic energy system (PV), wave energy sources and micro-turbines, these are used in hybrid energy systems (HESs) and also applicable in micro-grid system. These RES structures are not operated properly due to the various hazardous conditions (solar radiation, temperature, wind speed). Hence numerous solutions are found out to solve these problems. Hence storage systems are the best solution for the mitigation of the effect of solar, wind and other renewable sources. Storage systems are used to store the energy, also improves power quality. It is convenient to keep more than one storage system to minimize the variation of power as well as the storage systems provide high energy density [4], [5]. Hybrid Energy Systems (HESs) uses Battery Bank (BBs) and storage systems efficiently, but the life time durations of these batteries decrease according to its charging and discharging periods [6], [7]. Hence an alternative secondary energy sources is required which can replace the battery bank as well as increase the efficiency of Hybrid Energy Systems (HESs). So fuel cells are used now a days, these fuel cells are combine with electrolyzer and gives power supply continuously to the load given in [8], [9].Hence the hybrid energy system (HESs) consists of PV, wind energy (WT) and fuel cell (FC) combine with the electrolyzer gives the better energy management strategies and more effective in practice for the requirement of higher energy and the uses of DC loads are more promising in today's world such as they are used in commercial ,residential and industrial buildings. So, these loads are DC dominated in the mean time [10]. Hence the AC grids are used to supply these DC loads. So, DC/DC and 
AC/DC converters are used more in the nearer days. So, the cost of the system is increased and gives the additional losses. So, the system efficiency is reduced. A HES containing an individual AC grid as well as a DC grid, which can overcome the problem that the DC loads are connected to the DC grid given in [11]-[13] and $\mathrm{AC}$ are connected to the AC grid. Hence bidirectional converters are used in DC as well as AC grids [14].

The literature consists of a PV system, SOFC, electrolyzer and a storage tank which are simulated with each other, latter this combination connected the grid. Advantage of This technology gives better performances to the DC as well as AC grids. Hence hybrid energy system increases the quality of power management of the grid. This article concluded overall description as well as provides the information about the proposed technology. Detailed modeling and controlling strategy of the system equipments are given. Further the proposed technology is verified for its performances and effectiveness under the simulation consisting of several situations.

\section{EXPLANATION OF GRID CONNECTED HYBRID GENERATION SYSTEM}

Figure 1 shows the proposed model which consists of PV system with the maximum power point tracker (MPPT) interfacing with the DC/DC converter (boost converter) to increase the DC voltage. DC/AC converters (Inverters) are used to convert DC to AC, when DC voltage of PV with MPPT having boost converter ( $\mathrm{Vpv}$ _boost) is applied to this. Energy coming from the sun depends according to the various weather conditions. so, the solar radiation is not constant in every period, it may be weak or strong or absent.

So, the integration of SOFC in the HESs makes the HESs more sustainable. When the Power generation is greater than the required amount, then the electrolyzer come to the front to take excess generated power and converts the water in to hydrogen and oxygen by electrolysis process. Storage tank stores this hydrogen in compressed form and used as a fuel of SOFC.

Hybrid Energy System (HES) develops a power management strategy, which can decrease the effect of daily or seasonal variations due to the different climatic conditions. Hence HES provides a better output power, which can fulfill the requirement of power. In this proposed technology different types of faults are given, hence the stability and performances of the HES is analyzed.

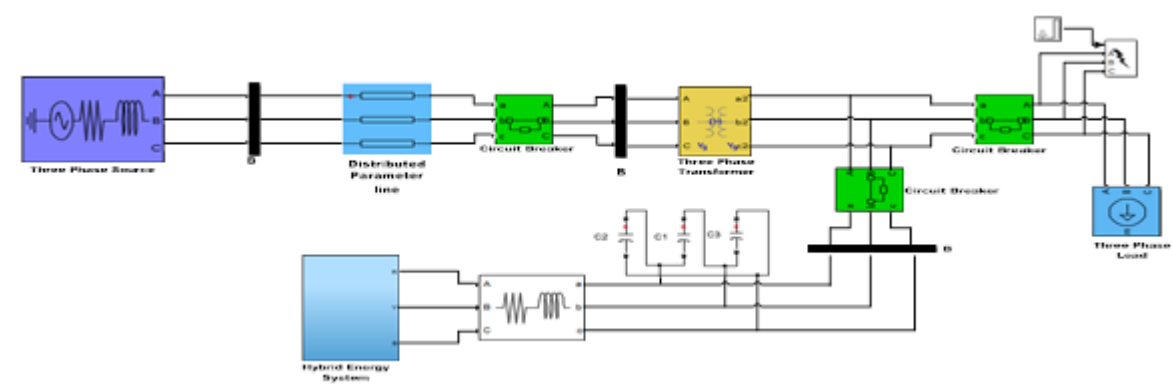

Figure 1. Hybrid system connected to grid (proposed model)

\section{PHOTOVOLTAIC (PV) SYSTEM}

The PV system mathematical model is represented in [15] and the maximum amount of power can be withdrawn from PV array with the help of MPPT; then DC/DC converter (boost converter) are used to boost up the voltage level and connected to the DC/AC inverter.

Then the PV system is designed by considering (1) with the help up MATLAB/SIMULINK software and Table 1 shows the specifications of the photovoltaic (PV) array.

$$
V_{p v}=\frac{N_{S} a k T}{q} \ln \left[\frac{I_{S c}-I_{p v}+N_{p}}{N_{p} I_{O}}\right]-\frac{N_{S}}{N_{p}} R_{s} I_{p v}
$$

Parameters are considered for designing of the PV system such as, $\mathrm{I}_{0}$ is the reverse saturation current of PV model in $[\mathrm{A}], \mathrm{I}_{\mathrm{SC}}$ is the short-circuit PV cell current in $[\mathrm{A}], \mathrm{I}_{\mathrm{PV}} / \mathrm{I}_{\mathrm{ph}}$ is the output current of PV model in [A], $\mathrm{k}$ is the boltzmann's constant in $\left[\mathrm{J} /{ }^{\circ} \mathrm{K}\right]$, a is the completion or ideality factor, $\mathrm{q}$ is the electron charge in $[C], R_{P}$ in the parallel resistance of the PV model in $[\Omega], R_{S}$ in the series resistance of PV model in $[\Omega], N_{S}$ is the no. of cells are connected in series in a string of the PV model, $\mathrm{N}_{\mathrm{P}}$ is the no. of parallel strings, $\mathrm{T}$ is the 
temperature in [K], $\mathrm{V}_{\mathrm{PV}}$ is the terminal voltage of the PV model in volt in [V], $\mathrm{V}_{\mathrm{MP}}$ is the maximum power of the PV cell in volt in [V], VOC is the open-circuit voltage of the PV cell in volt in [V]

Table 1. Specifications of Photovoltaic (PV) ARRAY

\begin{tabular}{ll}
\hline Specification & Value \\
\hline No. of series connected PV cell & 96 \\
No. of Modules in parallel & 66 \\
No. of Modules in series & 05 \\
Open circuit voltage $\left(\mathrm{V}_{\mathrm{OC}}\right)$ & $64.2 \mathrm{~V}$ \\
Short circuit current $\left(\mathrm{I}_{\mathrm{SC}}\right)$ & $5.96 \mathrm{~A}$ \\
Maximum Power of PV cell & $305 \mathrm{~W}$ \\
Temperature $(\mathrm{T})$ & 25 \\
Irradiance & 1000 \\
\hline
\end{tabular}

\section{MODELLING AND SIMULATION OF ELECTROLYZER}

Water is decomposed into two parts, one is hydrogen $\left(\mathrm{H}_{2}\right)$ and another one is oxygen, by electrolysis process when electric current is flowing through the electrolyzer, which contains two individual electrodes [16]. The equation of electrolysis of water is represented below:

$$
\mathrm{H}_{2} \mathrm{O}(\mathrm{I})+\text { electrical energy }=\mathrm{H}_{2}(g)+\frac{1}{2} \mathrm{O}_{2}(g)
$$

Parameters are used to design electrolyzer model such as, $\mathrm{i}_{\mathrm{e}}$ is the current of an electrolyzer in [A], $\mathrm{n}_{\mathrm{c}}$ is the no. of electrolyzer cells connected in series, $\mathrm{nH}_{2}$ is the hydrogen generation in moles per second in the $\left[\mathrm{mol} \mathrm{s}^{-1}\right], \mathrm{F}$ is the faraday constant in the $\left[\mathrm{C} \mathrm{kmol}^{-1}\right], \eta_{\mathrm{F}}$ is the Faraday efficiency.

Generation of hydrogen of an electrolyzer is directly proportional to the electric current, which is related to the Faraday's law, is given below [16]. The electrolyzer model is simulated with the help of simulink by using (3) and (4).

$$
n H_{2}=\frac{n_{F} n_{c} i_{e}}{2 F}
$$

The ratio between hydrogen generations by the help electrolyzer to the actual value is given as Faraday efficiency.

$$
\eta_{F}=96.5 e^{\left(\frac{0.09}{i_{e}}-\frac{75.5}{i_{e}^{2}}\right)}
$$

\section{MODELLING AND SIMULATION OF STORAGE TANK}

Electrolyzer is used to generate the hydrogen by the help of electrolysis process; then this hydrogen is used as the input fuel of SOFC. So SOFC consumes the required amount hydrogen according to the power requirement. The rest amount of hydrogen is stored in the storage tank after the use of hydrogen as a fuel to SOFC, which is the difference of the generated hydrogen and the required hydrogen used by SOFC.

The hydrogen storage tank stores the hydrogen in compressed manner either it is stored in liquid or gasses manner. From (5) is used for simulation and design of a hydrogen storage tank according to [16].

$$
P_{b}-P_{b i}=z \frac{\mathrm{NH}_{2} R T_{b}}{M H_{2} V_{b}}
$$

Parameters are used to design the Storage Tank such as, $\mathrm{Z}$ is the pressure compressibility factor, $\mathrm{NH}_{2}$ is the amount of hydrogen stored in the storage tank in moles per second in the $\left[\mathrm{kmol} \mathrm{s}^{-1}\right], \mathrm{MH}_{2}$ is the Hydrogen molar mass in $\left[\mathrm{kg} \mathrm{kmol}^{-1}\right], \mathrm{Tb}$ is operating temperature in $\left[{ }^{\circ} \mathrm{K}\right], \mathrm{P}_{\mathrm{bi}}$ is the storage tank pressure at initial stage in $[\mathrm{Pa}], \mathrm{P}_{\mathrm{b}}$ is the storage tank pressure in $[\mathrm{Pa}], \mathrm{R}$ is the Rydberg/Universal gas constant in [ $\mathrm{J}$ $\left.\left(\mathrm{kmol}^{\circ} \mathrm{K}\right)^{-1}\right], \mathrm{V}_{\mathrm{b}}$ is the storage tank volume in $\left[\mathrm{m}^{3}\right]$.

\section{DETAILED MODELLING OF SOFC}

Parameters are used to develop a mathematical model of the solid oxide fuel cell (SOFC), which is shown below according to [17] such as, B and C is the activation voltage constants in SOFC system in [V], $\mathrm{CV}$ is the conversion factor in $\left[\frac{\text { Hydrogen }(\mathrm{kmoh})}{\text { Methen }(\mathrm{kmoh})}\right], \mathrm{E}_{0}$ is the normal no load voltage in $[\mathrm{V}], \mathrm{E}$ is the nernst 
immediate voltage in [V], $\mathrm{F}$ is the Faraday's constant in $\left[\mathrm{C}\left(\mathrm{kmol}^{-1}\right)\right], \mathrm{I}_{\mathrm{FC}}$ is the feedback current of SOFC in [A], $\mathrm{k}_{1}$ is the gain of PI (proportional-integral), $\mathrm{K}_{\mathrm{an}}$ is the anode valve constant in $\left[\sqrt{\mathrm{kmol} \mathrm{kg}}(\operatorname{atm~s})^{-1}\right], \mathrm{K}_{\mathrm{r}}$ is the modeling constant in $\left[\mathrm{kmol} \mathrm{SA}^{-1}\right], \mathrm{K}_{\mathrm{H} 2 \mathrm{O}}$ is the molar constant of water valve in [ $\left.\mathrm{kmol}^{(\mathrm{atm} \mathrm{s}} \mathrm{s}^{-1}\right)$, $\mathrm{K}_{\mathrm{H} 2}$ is the molar constant of hydrogen valve in $\left[\mathrm{kmol}\left(\mathrm{atm} \mathrm{s}^{-1}\right)\right], \mathrm{K}_{\mathrm{O} 2}$ is the molar constant of oxygen valve in [ $\mathrm{kmol}$ $\left.\left(\operatorname{atm~s}{ }^{-1}\right)\right], \mathrm{M}_{\mathrm{H} 2}$ is the hydrogen molar mass in $\left[\mathrm{kg} \mathrm{kmol}^{-1}\right], \mathrm{P}_{\mathrm{H} 2 \mathrm{O}}$ is the water fractional pressure in [atm], $\mathrm{P}_{\mathrm{H} 2}$ is the hydrogen fractional pressure in [atm], $\mathrm{P}_{\mathrm{O} 2}$ is the oxygen fractional pressure in [atm], $\mathrm{N}_{0}$ is the no. of fuel cells are in series in a stack, $\mathrm{q}_{\mathrm{H} 2}$ is the molar flow of hydrogen in $\left[\mathrm{kmols}^{-1}\right]$, $\mathrm{q}_{\text {methane }}$ is the methane flow rate in $\left[\mathrm{kmols}^{-1}\right], \mathrm{q}_{\mathrm{O} 2}$ in the input molar flow of oxygen, $\left[\mathrm{kmols}^{-1}\right], \mathrm{q}_{\mathrm{H} 2}^{\mathrm{in}}$ is the input flow of hydrogen in $\left[\mathrm{kmols}^{-1}\right], \mathrm{q}_{\mathrm{H} 2}^{\mathrm{ut}}$ is the hydrogen output flow in $\left[\mathrm{kmols}^{-1}\right], \mathrm{q}_{\mathrm{H} 2}^{\mathrm{r}}$ is the hydrogen flow amount that reacts in $\left[\mathrm{Kmols}^{-1}\right], \mathrm{q}_{\mathrm{H} 2}^{\text {req }}$ is the hydrogen flow amount that meets load change in $\left[\mathrm{kmols}^{-1}\right], \mathrm{R}$ is the rydberg (Universal) gas constant in $\left[(1 \mathrm{~atm})(\mathrm{kmol} \mathrm{K})^{-1}\right], \mathrm{R}_{\mathrm{int}}$ is the internal resistance of SOFC in $[\Omega], \mathrm{T}$ is the absolute temperature in $[\mathrm{K}], \mathrm{U}$ is the utilization rate, $\mathrm{V}_{\mathrm{an}}$ is the volume of the anode in $\left[\mathrm{m}^{3}\right], \mathrm{V}_{\text {cell }}$ is the SOFC dc output voltage in $[\mathrm{V}], \tau_{1}, \tau_{2}$ is the reformer time constants in [s], $\tau_{3}$ is the PI controller time constant in [s], $\tau_{\mathrm{H} 2}$ in the hydrogen time constant, [s], $\tau_{\mathrm{H} 2 \mathrm{O}}$ is the water time constant in [s], $\tau_{\mathrm{O} 2}$ is the oxygen time constant in [s], $\mathrm{Z}_{\mathrm{act}}$ is the activation over voltage in [V], $\mathrm{Z}_{\text {ohmic }}$ is the ohmic over voltage in [V].

The ratio between the molar flows of hydrogen through the valve to the hydrogen partial pressure in a channel can be given as [17].

$$
\frac{q_{H 2}}{P_{H 2}}=\frac{K_{a n}}{\sqrt{M_{H 2}}}=K_{H 2}
$$

Molar flow of hydrogen is calculated by taking the derivative of the partial pressure, which shows the perfect gas equation as given in [17].

$$
\frac{d}{d t} p_{H 2}=\frac{R T}{V_{a n}}\left(q_{H 2}^{\text {in }}-q_{H 2}^{\text {out }}-q_{H 2}^{r}\right)
$$

Relationship between hydrogen flow and SOFC current determines the rate of reacted hydrogen flow according to [17].

$$
q_{H 2}^{r}=\frac{N_{0} I_{F C}}{2 F}=2 K_{r} I_{F C}
$$
as [16].

The partial pressure of hydrogen can be determined by considering the Laplace transform of (6)-(8)

$$
P_{H 2}=\frac{1 / K_{H 2}}{1+\tau_{H 2} S}\left(q_{H 2}^{i n}-2 K_{r} I_{F C}\right)
$$

Where, $\tau_{H 2}=\frac{V_{a n}}{K_{H 2} R T}$

In this manner oxygen partial pressure and water partial pressure can be determined. The output voltage of the fuel cell can be obtained by considering the summation of three factors; these are activation overvoltage of the anode and cathode, Nernst potential and ohmic overvoltage of internal resistance as given in [17].

$$
V_{\text {cell }}=E+\eta_{\text {act }}+\eta_{\text {ohmic }}
$$

Where, $\eta_{\text {act }}=-B \ln \left(C I_{F C}\right)$

And $\quad \eta_{\text {ohmic }}=-R^{\text {int }} I_{F C}$

So, Nernst instantaneous voltage can be determined as given in [17].

$$
E=N_{O}\left[E_{O}+\frac{R T}{2 F} \log \left[\frac{P_{H 2} \sqrt{P_{O 2}}}{P_{H 2 O}}\right]\right]
$$


The hydrogen acts as a fuel of SOFC power plant which can able to fulfill the power demand according to its requirement. Hence the supply of hydrogen is continuous for the stack operation of SOFC. The model of the reformer can be expressed as [17].

$$
\frac{q_{H 2}}{q_{\text {methanol }}}=\frac{C V}{\tau_{1} \tau_{2} s^{2}+\left(\tau_{1}+\tau_{2}\right) s+1}
$$

A PID controller is used to control the flow of hydrogen according to the requirement of output power of SOFC system. SOFC output current is taken as a input of the SOFC to obtain the feedback control [17], given by

$$
q_{H 2}^{r e q}=\frac{N_{O I} F C}{2 F U}
$$

The available hydrogen of the reformer is used to control the flow of methane by the help of PI controller [17], which can be determined as shown below.

$$
q_{\text {methane }}=\left(k_{1}+\frac{k_{1}}{\tau_{3} s}\right)\left(\frac{N_{O} I_{F C}}{2 F U}-q_{H 2}^{i n}\right)
$$

By considering the above parameters a $5 \mathrm{KW}$ SOFC model is obtained as given in Table 2. A SOFC

\begin{tabular}{|c|c|}
\hline Specifications & Value \\
\hline Activation voltage constant (B) & $0.04777\left[\mathrm{~A}^{-1}\right]$ \\
\hline Activation voltage constant (C) & $0.0136[\mathrm{~V}]$ \\
\hline Conversion factor $(\mathrm{CV})$ & 2 \\
\hline Faraday's constant $(\mathrm{F})$ & $96484600\left[\mathrm{Ckmol}^{-1}\right]$ \\
\hline FC system internal resistance $\left(R_{\text {int }}\right)$ & $0.26664[\Omega]$ \\
\hline FC absolute temperature $(\mathrm{T})$ & $343[\mathrm{~K}]$ \\
\hline Hydrogen time constant $\left(\tau_{\mathrm{H} 2}\right)$ & $3.37[\mathrm{~s}]$ \\
\hline Hydrogen valve constant $\left(\mathrm{K}_{\mathrm{H} 2}\right)$ & $4.22 \times 10^{-5}\left[\mathrm{kmol}(\mathrm{s} \mathrm{atm})^{-1}\right]$ \\
\hline Hydrogen-oxygen flow ratio $\left(\mathrm{r}_{\mathrm{H} 2 \mathrm{O}}\right)$ & 1.168 \\
\hline $\mathrm{Kr}$ constant $=\mathrm{N}_{0} / 4 \mathrm{~F}$ & $2.2802 \times 10^{-7}\left[\mathrm{kmol}(\mathrm{s} \mathrm{A})^{-1}\right.$ \\
\hline Line reactance $(\mathrm{X})$ & $0: 0809[\Omega]$ \\
\hline Methane reference signal $\left(Q_{\text {methref }}\right)$ & $0.000015\left[\mathrm{kmol} \mathrm{s}^{-1}\right]$ \\
\hline No load voltage $\left(\mathrm{E}_{\mathrm{o}}\right)$ & $1.18[\mathrm{~V}]$ \\
\hline Number of cells $\left(\mathrm{N}_{\mathrm{o}}\right)$ & 88 \\
\hline Number of stacks $\left(\mathrm{N}_{\mathrm{S}}\right)$ & 1 \\
\hline Oxygen time constant $\left(\tau_{\mathrm{O} 2}\right)$ & $6.74[\mathrm{~s}]$ \\
\hline Oxygen valve constant, $\left(\mathrm{k}_{\mathrm{O} 2}\right)$ & $2.11 \times 10^{-5}\left[\mathrm{kmol}\left(\mathrm{s} \mathrm{atm}^{-1}\right]\right.$ \\
\hline PI gain constant $\left(\mathrm{k}_{1}\right)$ & 0.25 \\
\hline Reformer time constant $\left(\tau_{1}, \tau_{2}, \tau_{3}\right)$ & $15[\mathrm{~s}]$ \\
\hline Universal gas constant $(\mathrm{R})$ & $8314.47\left[\mathrm{~J} \mathrm{kmolK}^{-1}\right]$ \\
\hline Utilization factor $(\mathrm{U})$ & 0.8 \\
\hline Water time constant $\left(\tau_{\mathrm{H} 2 \mathrm{O}}\right)$ & $18.418[\mathrm{~s}]$ \\
\hline Water valve constant $\left(\mathrm{K}_{\mathrm{H} 2 \mathrm{O}}\right)$ & $7.71610^{-6}\left[\mathrm{kmol}(\mathrm{s} \mathrm{atm})^{1}\right]$ \\
\hline
\end{tabular}
brief model is represented in simulink as given in [18]. Three $5 \mathrm{KW} \mathrm{SOFC}$ are used in this proposed system.

Table 2. Specifications of SOFC to design the mathematical model

\section{INTERNAL STRUCTURE OF HYBRID ENERGY SYSTEM}

Figure 2 gives the information about the block diagram of Hybrid Energy System (HES), which is represented in Figure 1. By using the MPPT in the PV system maximum amount of power can be tracked. Then the PV power is used to manage the power demand of the load as well as the rest amount of PV power is utilized to convert the water in to hydrogen and oxygen with the help of electrolyzer by the electrolysis process and this generated hydrogen is used as the input fuel of the SOFC shown in Figure 2(b). The DC/DC converter is connected to PV system with MPPT to increase the voltage of PV system (Vpv_boost). This DC/DC converter is triggered by the gate pulse which is generated from the MPPT as shown in Figure 2(a). Again, another DC/DC converter (boost converter) is connected to the SOFC to increase the voltage level of the SOFC voltage as shown in Figure 2(b).

The PV system and SOFC boost converter are connected to common DC bus. Hence the DC voltage of the common DC bus is supplied to DC/AC converter (Inverter). So, the DC voltage is converted to AC voltage by the help of DC/AC converter shown in Figure 2(a). Then the output of the DC/AC converter is connected to grid. To synchronize the grid with hybrid energy system (HES) a voltage source inverter (VSC) 
is used and DC/AC converter is triggered by the gate pulse provided by the VSC controller as shown in Figure 2(a).

VSC controller is used to synchronize the HES voltage to the grid voltage. Hence grid voltage and frequency are utilized for the DC/AC converter operation.VSC is the combination of two cascaded control loop, one is voltage controller of DC link and another one is internal current loop.

a. Voltage controller of $D C$-link

The desired value of active power is controlled by DC-link voltage. The $\mathrm{i}_{\mathrm{d}} *$ is the output current of DClink PI controller and it is used as the reference current or active current controller shown in Figure 2(c).

b. Internal current loop

The $d \rightarrow q$ control (Synchronous Reference Frame) is used for transformation of grid voltage $\left(\mathrm{V}_{\mathrm{a}}, \mathrm{V}_{\mathrm{b}}\right.$, $\mathrm{V}_{\mathrm{c}}$ ) and grid current $\left(\mathrm{i}_{\mathrm{a}}, \mathrm{i}_{\mathrm{b}}, \mathrm{i}_{\mathrm{c}}\right)$ to dq reference frame which rotates synchronously along with grid voltage. With the help of $d \rightarrow q$ controller, the DC values are obtained by controlling the variables. So, for the designing and controlling purposes DC values are easier than AC values. Phase angle of the grid voltage is derived by using the PLL (Phase Lock Loop). PLL also used for transformation of abc $\rightarrow \mathrm{dq}$ and also used for synchronization of grid voltage and controlled current. The phase angle is derived from the grid voltage by using the PLL technique. The value of reference reactive current $\left(\mathrm{i}_{\mathrm{q}}{ }^{*}\right)$ is taken as zero as shown in Figure 2(c). So, power factor (pf) is maintained as one (Unity). The output voltages $\left(\mathrm{V}_{\mathrm{d}^{*}}, \mathrm{~V}_{\mathrm{q}}{ }^{*}\right)$ is provided by the PI controller and these output voltages are used as the input to the PWM generator, which produce pulses and given to the DC/AC converter to trigger [19].

From the Figure 2(b), a DC/DC converter (buck converter) is connected to the electrolyzer. So, the extra amount of power of the PV system is send to the electrolyzer through this buck converter. From the electrolyzer hydrogen and oxygen is extracted from the water and the hydrogen is used as the input fuel of SOFC. The hydrogen requirement of the SOFC depends upon the load requirement. Storage tank stores the rest amount of hydrogen, which is the difference between the generated hydrogen of an electrolyzer and required hydrogen of the SOFC.

The block diagram of the fuel cell controller is shown in Figure 2(d). Voltage (Vsofc_boost) of the boost converter, which is connected to the SOFC, is applied to the PID controller. Then the valve is regulated by the PID controller according to the load requirement. So, the valve is decided to take the required amount of hydrogen through it and supplied to the SOFC. PID controller regulates the valve according to the load. The values are decided by the help of self tune mode of the PID controller, which are applied in PID controller ( $\mathrm{P}=0.00013317$, I=3.3925227e-05, $\mathrm{D}=-6.254254172870 \mathrm{e}-05)$.

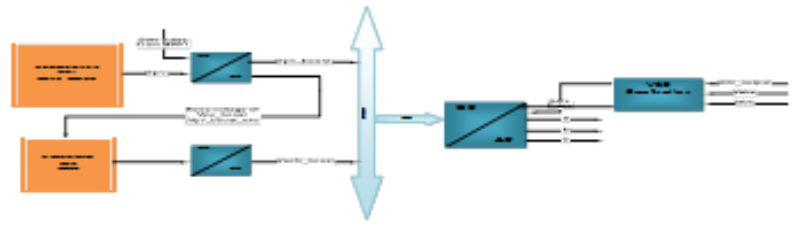

(a) Block diagram of hybrid energy system (HES)

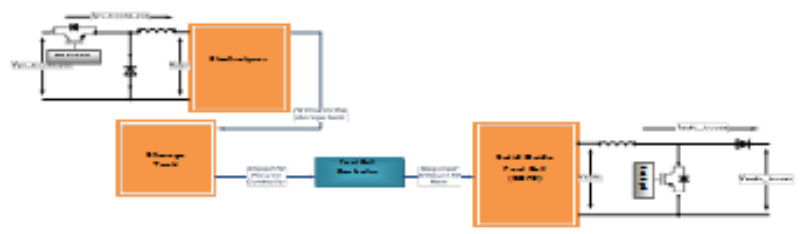

(b) Block diagram representation of hydrogen flow from electrolyzer to SOFC

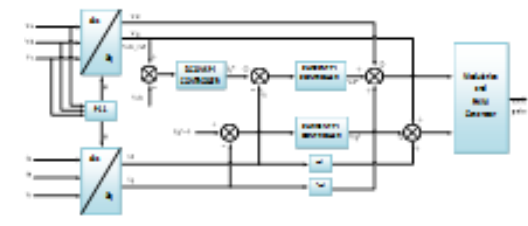

(c) Block diagram representation of voltage source inverter (VSC)

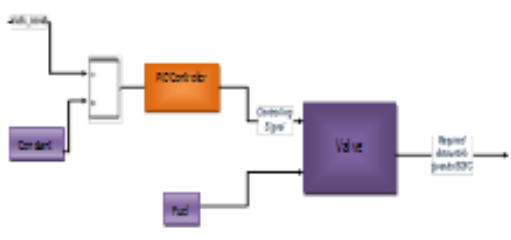

(d) Block diagram representation of fuel cell controller

Figure 2. A detailed structure of HES

\section{FAULT ANALYSIS OF THE PROPOSED SYSTEM}

Various types of fault such as symmetrical fault (Line to line to line fault or LLL fault, Line to line to line to ground fault or LLLG fault) and unsymmetrical fault (Line to ground fault or LG fault, Line to line fault or LL fault, Line to line to ground fault or LLG fault) occurs in the distribution network or at the load side which affects the supply voltage, current also affects the system performances according to [20], [21]. Hence the proposed system is verified under these various fault conditions. 
So, fault analysis is performed on hybrid energy system connected to grid in MATLAB/Simulink environment as shown in Figure 1, hence the behavior of the proposed system is analyzed during the healthier condition and also the condition when fault occurs in the proposed system. In this proposed system both symmetrical as well as unsymmetrical fault are given and their effects are analyzed.

\section{OPERATIONAL CONTROL STRATEGY OF HYBRID ENERGY SYSTEM}

Operational control strategy (OCS) or supervisory control strategy (SCS) of the hybrid energy system is necessary to regulate the hybrid energy system as well as the load demand according to their effectiveness. Hence operational control strategy contains the four possible ways to regulate both the load demand and OCS.

a. When Load demand (Pload) is smaller than the PV power (Ppv) [Ppv < Pload], at that time the required amount of PV power is used to fulfill the required load. Then the extra PV power is used for electrolysis process of the electrolyzer, where two basic elements such as hydrogen and oxygen are derived from the water. Hence the generated hydrogen is kept in a storage tank; later this hydrogen is used as a fuel of SOFC by flowing through the valve.

b. When Load demand (Pload) is greater than PV power (Ppv) [Pload > Ppv], at that time to fulfill the required amount load, there is no sufficient PV power is available. So, the extra amount power is needed for the required load, which is provided by the SOFC.

c. When the Load demand (Pload) is equal to the PV power (Ppv) [Pload = Ppv], at that time the load consumes the total available PV power. Hence the electrolyzer is not supplied from PV system.

d. When generated PV power (Ppv) is zero [Ppv $=0]$, at that time, there is no supply available from the PV system. Hence SOFC is used to fulfill the load requirement.

In this manner the four possible ways are find out for the operational control strategy to regulate the whole system.

\section{SIMULATION RESULTS AND DISCUSSIONS}

The proposed system (PV/SOFC/Electrolyzer/Storage tank) is designed by using the software MATLAB/Simulink, also different simulation is done and verified according to the system performances.

Figure 3 shows the hydrogen generation and flow of hydrogen to the SOFC, also its flow is controlled by the PID controller through the valve. So, Figure 3(a) shows the hydrogen generation by the electrolyzer. Figure 3(b) shows the requirement of hydrogen flow to the SOFC according to the Load demand through the valve, which is controlled by the PID controller. Hence the PID controller output is shown in Figure 3(c). The output voltage of SOFC (Vsofc) is applied to DC/DC converter (Boost converter) as shown in Figure 2(b), where the voltage Vsofc is increased to Vsofc_boost (Voltage of boost converter connected to SOFC to increase the voltage Vsofc) as shown in Figure 3(d).

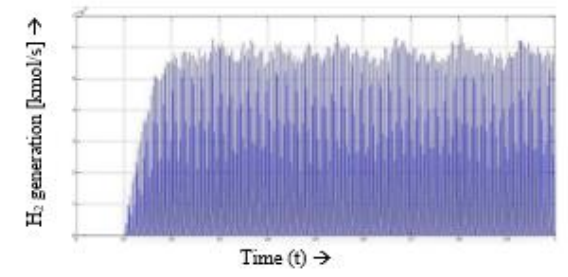

(a) $\mathrm{H}_{2}$ generation by electrolyzer

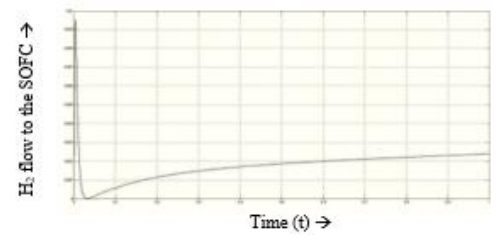

(b) $\mathrm{H}_{2}$ flow to the SOFC.

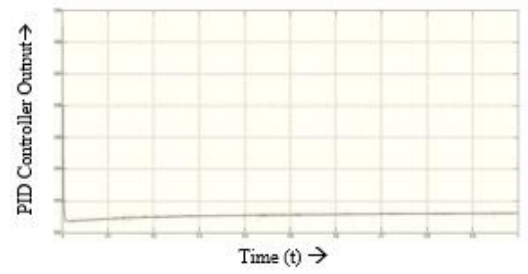

(c) PID controller output

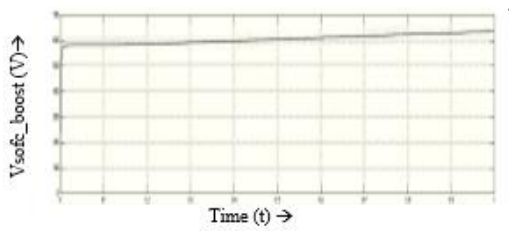

(d) Output voltage of boost converter connected to SOFC

Figure $3 . \mathrm{H}_{2}$ flow to SOFC and boost voltage of DC-DC converter connected to SOFC 
Figure 4 shows the voltage and current wave form of the hybrid energy system (HES) on the healthier condition. But Figure 5 shows the voltage and current waveform of HES on L-G fault condition. Before fault occurs, the voltages of HES are remained constant but on the occurrence of L-G fault at the duration of 0.3 to $0.4 \mathrm{sec}$, then the voltage of faulted phase is equal to zero and other phases are in normal condition. When the fault is removed at $0.4 \mathrm{sec}$, the voltage of faulted phase is settled to its normal value after $0.4 \mathrm{sec}$. During the fault the currents of the faulted phases are increased. When the fault is removed; then the currents come to their original values. In this manner other faults of HES can be determined.

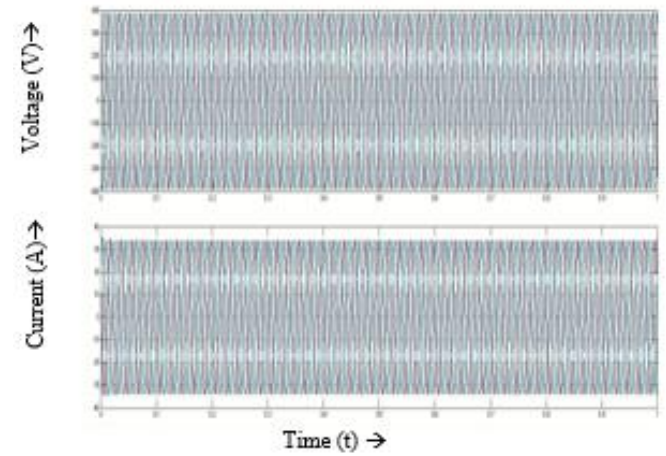

Figure 4. Voltage and current waveforms of hybrid energy system (HES)

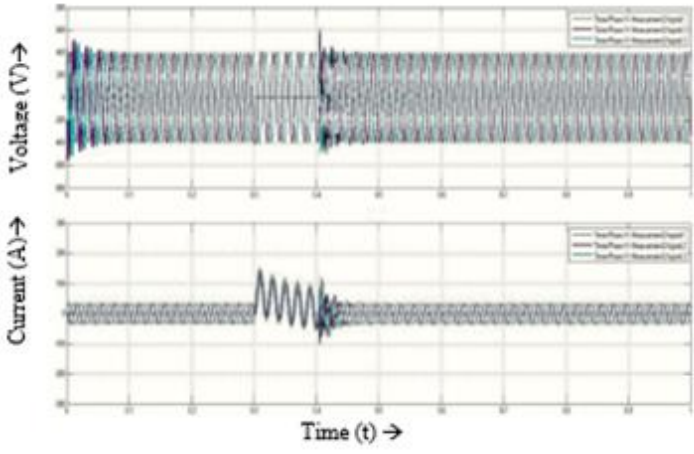

Figure 5. Voltage and current waveforms of HES during L-G fault

Figure 6 gives the waveform of voltage, current and power of $3 \varnothing$ load having the capacity of active power $(\mathrm{P})=8000 \mathrm{~W}$, inductive power $\left(\mathrm{Q}_{\mathrm{L}}\right)=2000 \mathrm{VAR}$ and capacitive power $\left(\mathrm{Q}_{\mathrm{C}}\right)=100 \mathrm{VAR}$.

Figure 7 shows the symmetrical fault as well as unsymmetrical fault. From these Figures it can be seen before the fault occurs the voltage, current and power wave forms are with their appropriate values but when the fault occurs having the duration between $0.3 \mathrm{sec}$ to $0.4 \mathrm{sec}$ at that time voltage, current and power wave forms of the faulted phase are equal to zero. After the fault is removed at the time of $0.4 \mathrm{sec}$, then the corresponding voltage, current and power wave forms. In this manner other faults of $3 \varnothing$ load can be determined.

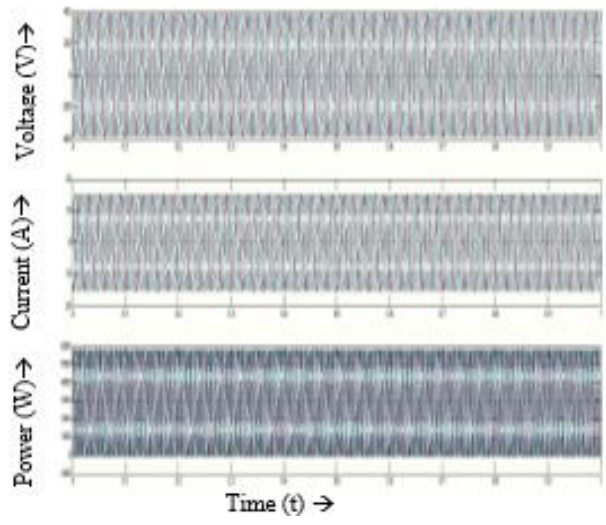

Figure 6. Voltage, current and power waveforms of 3-phase load

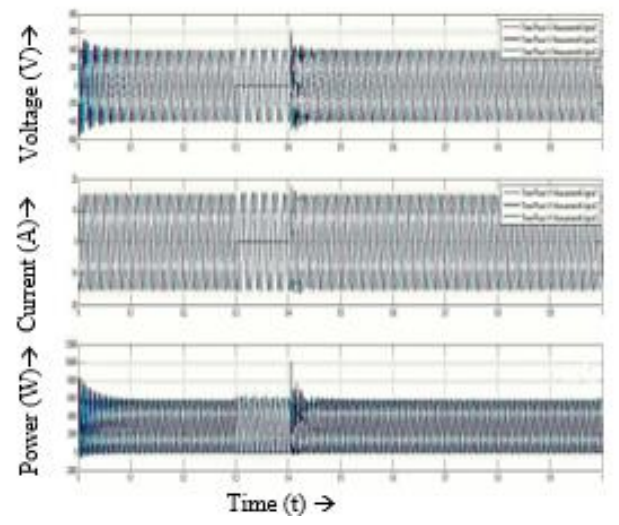

Figure 7. Voltage, current and power waveforms of 3-ø load under L-G fault

\section{CONCLUSION}

From this paper a detailed model of hybrid energy system combination of PV/FC/Electrolyzer and storage tank is determined. The system configuration and the characteristics of the different components are verified as well as the power management strategy and overall control strategies of the system are given. In this proposed system the PV cell is the main generating source and used to fulfill the load requirement. Excess power of PV is used for the production of hydrogen from the electrolyzer. When the PV power is not 
sufficient to fulfill the load requirement at that time SOFC is used to fulfill the required load by taking the hydrogen as a fuel; also, the amount of fuel flow through the valve is consumed by the SOFC is determined by the PID controller.

Different types of fault analysis are considered on the proposed system and verified the effects due to these faults. Again, the performances of the system are verified by the help of simulations at different conditions. Further, the obtained results are conformed and provide the satisfactory performances. A better power management as well as control strategy are used for fulfillment of the the load requirement under the various critical and unfavorable situations.

In this proposed system the hybrid energy system is connected to the grid with the help of VSC which gives the better results as well as better performances

\section{REFERENCES}

[1] S. Tamalouzt, et al., "Performances analysis of WT-DFIG with PV and fuel cell hybrid power sources system associated with hydrogen storage hybrid energy system," International Journal of Hydrogen Energy, vol. 41, pp. 21006-21021, 2016

[2] Y. Bouzelata, et al., "Exploration of optimal design and performance of a Hybrid wind- solar energy system," International Journal of Hydrogen Energy, vol. 41, pp. 497-511, 2016.

[3] H. Yang, et al., "A novel optimization sizing model for hybrid solar-wind power generation system," Journal of Solar Energy, vol. 81, pp. 76-84, 2007.

[4] A. Etxeberria, "Comparison of three topologies and controls of a hybrid energy storage system for microgrids," Energy Conversion Management, vol. 54, pp. 113-121, 2012.

[5] S. Tamalouzt, et al., "A doubly fed induction generator wind turbine and fuel cell hybrid power sources system for micro-grid applications," $3^{\text {rd }}$ International Conference on Control Engineering \& Information Technology, Tlemcen, Algeria, pp. 25-27, May 2015.

[6] N. A. Ahmed, et al., "Development of an efficient utility interactive combined wind/photovoltaic/fuel cell power system with MPPT and DC bus voltage regulation," Electrical Power System Research, vol. 81, pp. 1096-1106, 2011.

[7] A. Maleki and A. Askarzadeh, "Comparative study of artificial intelligence techniques for sizing of a hydrogenbased standalone photovoltaic/wind hybrid system," International Journal of Hydrogen Energy, vol. 39, pp. 9973-9984, 2014.

[8] S. Obara, et al., "Economic efficiency of a renewable energy independent microgrid with energy storage by a sodium-sulfur battery or organic chemical hydride," Internal Journal of Hydrogen Energy, vol. 38, pp. 8888-8902, 2013.

[9] R. Sarrias-Mena, et al., "Electrolyzer models forhydrogen production from wind energy Systems," International Journal of Hydrogen Energy, vol. 40, pp. 2927-2938, 2015.

[10] X. Liu, et al., "A hybrid AC/DC micro-grid and its coordination Control", IEEE Transaction on Smart Grid, vol. 2, pp. 278-286, 2011.

[11] H. Milanda, et al., "Load control of a wind-hydrogen stand-alone power system," International Journal of Hydrogen Energy, vol. 31, pp. 1215-1235, 2006.

[12] C. Wang and M. Hashem Nehrir, "Power management of a standalone wind/photovoltaic/fuel cell Energy system", IEEE Transaction Energy Conversion, vol. 23, pp. 957-967, 2008.

[13] N. Samrat, et al., "Modeling, control, and simulation of battery storage photovoltaic-wave energy hybrid renewable power generation systems for island electrification in Malaysia," Science World Journal, vol. 21, pp. 1-2, 2014.

[14] A. Naderipour, et al., "A New Compensation Control Strategy for Grid-Connected Wind Turbine and Fuel Cell Inverters in a Microgrid," International Journal of Power Electronics and Drive System, vol.8, pp. 272-278, 2017.

[15] M. Abdulkadir, et al., "Modeling and Simulation of a Solar Photovoltaic System, Its Dynamics and Transient Characteristics in LABVIEW," International Journal of Power Electronics and Drive System, vol. 3, pp. 185-192, 2013.

[16] O. C. Onar, et al., "Dynamic modeling, design and simulation of a wind/fuel cell/ultra- capacitor-based hybrid power generation system," Journal of Power Sources, vol. 161, pp. 707-722, 2006.

[17] M. Uzunoglu and O.C. Onar, "Static VAR compensator based reactive power management for SOFC power plants," International Journal of Hydrogen Energy, vol. 33, pp. 2367-2378, 2008.

[18] G. K. Bayrak and M. Cebeci, "Grid connected fuel cell and PV hybrid Power generating system design with Matlab Simulink," International Journal of Hydrogen Energy, vol. 39, pp. 8803-8812, 2014.

[19] M. G. Molina and E. J. Espejo, "Modeling and simulation of grid-connected photovoltaic energy conversion systems," International Journal of Hydrogen Energy, vol. 39, pp. 8702-8707, 2014.

[20] P. K. Hota, et al., "Fault analysis of grid connected photovoltaic system," American Journal of Electrical Power and Energy Systems, vol. 5, pp. 35-44, 2016.

[21] A. Mohapatra and B. K. Panigrahi, "Detailed Analysis of Grid Connected distributed Generation Based Hybrid System under Different Fault Conditions", International Conference on Computation of Power, Energy, Information and Communication (ICCPEIC), Chennai, India, pp. 310-314, Oct 2014. 